\title{
Spatial distribution and environmental factors associated to phlebotomine fauna in a border area of transmission of visceral leishmaniasis in Mato Grosso do Sul, Brazil
}

\author{
Ana Rachel Oliveira de Andrade ${ }^{*}$, Baldomero Antonio Kato da Silva², Geucira Cristaldo ${ }^{3}$, \\ Sonia Maria Oliveira de Andrade ${ }^{4}$, Antonio Conceição Paranhos Filho ${ }^{5}$, Alisson Ribeiro ${ }^{5}$, Mirella Ferreira da Cunha Santos ${ }^{1}$ \\ and Renato Andreotti ${ }^{6}$
}

\begin{abstract}
Background: Mato Grosso do Sul has been undergoing a process of urbanization which results in loss of native vegetation. This withdrawal makes vectors of man and domestic animals closer, causing changes in the epidemiology of diseases such as American Visceral Leishmaniasis. The aim of the study was to evaluate the phlebotomine fauna and environmental issues related to the transmission of AVL in Ponta Porã, Mato Grosso do Sul, between 2009 and 2010.

Methods: Vegetation of the urban area was evaluated by Normalized Difference Vegetation Index (NDVI), Normalized Difference Water Index (NDWI) and Soil Adjusted Vegetation Index (SAVI).

Results: The results showed that the phlebotomine fauna of the city consists of five species, especially Lutzomyia longipalpis (Lutz and Neiva, 1912), the vector of Leishmania (Leishmania) infantum. Predominance of males was observed. The insects were captured in greater quantity in the intradomicile. Lu. longipalpis was the most frequent and abundant species, present throughout the year, with a peak population after the rainy season. Vectors can be found in high amounts in forest and disturbed environments.

Conclusions: The finding of $L u$. longipalpis in regions with little vegetation and humidity suggests that the species is adapted to different sorts of environmental conditions, demonstrating its close association with man and the environment it inhabits. The tourist feature of Ponta Porã reinforces its epidemiological importance as a vulnerable city. The geographical location, bordering Paraguay through dry border, makes possible the existence of a corridor of vectors and infected dogs between the two countries.
\end{abstract}

Keywords: Border area, Geotechnology, Phlebotomines

\section{Background}

Over the years, studies on the phlebotomine fauna have been carried out in countries bordering the state of Mato Grosso do Sul [1,2]. The growth in number of vectors, humans and dogs infected in the State leads to the development of studies in the cities in order

\footnotetext{
* Correspondence: racheloliveira_83@hotmail.com

${ }^{1}$ Post Graduate Program in Infectious and Parasitary Diseases, Federal University of Mato Grosso do Sul, Campus Universitário, s/n, Caixa Postal 549, CEP 79070-900 Campo Grande, Mato Grosso do Sul, Brasil

Full list of author information is available at the end of the article
}

to observe the epidemiological pattern of the disease [3-5].

The presence of sandflies is associated with disturbed or forested environments [6], so every time that factors such as vegetation, humidity and temperature of a site are analyzed, indirectly the development conditions of the vector are evaluated.

Antonialli et al. [7] used spatial analysis to demonstrate the evolutionary patterns of American visceral leishmaniasis in Mato Grosso do Sul state. Oliveira et al. [5] evaluated the influence of environmental variables by 
Normalized Difference Vegetation Index (NDVI) by correlating the distribution of Lu. Longipalpis, canine and human cases of AVL in Campo Grande. These studies show how geotechonologies can be used as an auxiliary method for detecting ecological changes and delineating risk areas, aiming to support the development of strategies for the control of leishmaniases.

The objective of this study was to evaluate the sandfly fauna and environmental issues related to the transmission of AVL in Ponta Porã, Mato Grosso do Sul, between the years 2009 and 2010.

\section{Methods}

\section{Study area}

The city of Ponta Porã is located in the south of Mato Grosso do Sul, in the microregion of Dourados, $326 \mathrm{~km}$ away from the capital, Campo Grande. The average alti-

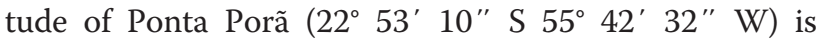
$655 \mathrm{~m}$ above sea level [8].

Its current population is 79,173 inhabitants, of whom $89 \%$ live in urban areas and $11 \%$ in rural areas, having a population density of 14.61 (inhabitants $/ \mathrm{km}^{2}$ ) [8].

As far as vegetation is concerned, there is predominance of grasslands as a characteristic of the city, formed by large areas of low grass, forming the famous natural pastures. Tropical highland climate with dry winters predominates in the area, with annual average temperature of $20.6^{\circ} \mathrm{C}$ and monthly average temperature of $23^{\circ} \mathrm{C}$.

The hottest month is February with an average temperature of $23.6^{\circ} \mathrm{C}$, and the coldest month is July, with a mean of $16.4^{\circ} \mathrm{C}$. The average annual rainfall is $1.660 \mathrm{~mm}$, with periods of wetter summers than the winter. The wettest month is November with an average of $212 \mathrm{~mm}$, while the driest is July, with an average of $55 \mathrm{~mm}$. It is under the influence of the Prata River Basin, being serviced primarily by Dourados River [8].

\section{Entomological data}

The phlebotomines were captured with CDC automatic light traps fortnightly installed at seven sites in Ponta Porã, both intradomicile and in the peridomiciles, totaling 14 ecotopes. Collections were carried out in the period between April 2009 and March 2010, from 6 pm to $6 \mathrm{am}$, disregarding the summer time change. The sites were chosen so they could comprise the whole urban area, considering the healthcare regions already defined for the municipality actions.

In one of the capture sites a white Shannon trap was installed on a monthly basis to check which sandfly species existed and their anthropophily.

The phlebotomines captured with CDC were separated from other insects; males and females were placed on Petri dishes and taken to the Parasitology Laboratory of the Federal University of Mato Grosso do Sul, where they were clarified according to Foratinni's methodology and then arranged on plates [9].

The structures of the head, thorax and abdomen were used for species identification. In specific levels the emphasis was given to the classification proposed by Galati $[10,11]$ and the abbreviation proposed by Marcondes [12].

\section{Environmental analysis}

As cartographic basis we have used an image taken from Landsat 5 TM, orbit-point 225/076, on August $18^{\text {th }} 2010$, freely available on the National Institute for Space Research's website [13].

For georeferencing, a previously corrected orthorectified image of Landsat 7 ETM+, orbit-point 225/076 of April $8^{\text {th }} 2000$, was used. The projection and datum used were respectively UTM (zone 21) and WGS84 [14].

The atmospheric correction of the image was made in software Geomatica, through algorithm atcor2 [15]. On the corrected image, Normalized Difference Vegetation Index (NDVI), Normalized Difference Water Index (NDWI) and Soil Adjusted Vegetation Index (SAVI) were calculated [16].

NDVI allows the characterization of biophysical parameters of vegetation, such as biomass/density of vegetation and its value is normalized to the range of -1.00 to +1.00 . These values represent an indirect measurement of phytomass, indicating values of matter and energy present in the sampled area [17].

NDVI is calculated by the following equation:

$$
\mathrm{NDVI}=\mathrm{NI}-\mathrm{RNIR}+\mathrm{R}
$$

where:

NIR: reflectance of vegetation in the near infrared band.

R: Reflectance of vegetation in the red band.

Concerning the limitations caused by the noise of background soil on NDVI, SAVI was used, ranging from +0.00 to 1.00 , an index proposed by Huete [18], that allows adjustment of the background soil (L).

$$
\mathrm{SAVI}=(1+\mathrm{L}) \mathrm{NIR}-\mathrm{RNIR}+\mathrm{R}+\mathrm{L}
$$

NDWI reflects the water content in vegetation (Vegetation Water Index - VWC). VWC is an important parameter in studies of vegetation and soil moisture with values ranging from -1.00 to +1.00 . Gao [19] developed NDWI for determining VWC, and NDWI is given by:

$$
\text { NDWI = NIR-SWIRNIR + SWIR, }
$$

where NIR is the reflectance of vegetation in the near infrared band, and SWIR is the reflectance of vegetation in the mid-infrared band. 


\section{Statistical analysis}

The proportion of genders was compared with the Z-test and p-value to test the hypothesis. The same test was used to compare the capture condition (intra or peridomicile). Correlations between number of specimens and georeferenced data, canine cases and georeferenced data, number of exemplars caught and number of canine cases, and number of $\mathrm{Lu}$. longipalpis and number of human cases were realized with Spearman's Correlation Coefficient. In all cases, the p-value used to demonstrate statistical significance was 0.05 . All statistical analysis was calculated using Bioestat 5.0.

\section{Ethics statement}

The study received approval from the local Animal Experimentation Ethics Committee (CEUA/UFMS) under protocol number 206/2009. Capture sites were located in private areas, and all owners gave permission to conduct the study in these sites. The field studies did not involve endangered/protected species or protected areas.

\section{Results}

A total of 707 insects were captured by automatic modified light traps (565 males and 142 females), in a ratio of males to females of $3,97: 1$ ( $p<0.0001$ ). Of the speciemens collected, 435 (61.5\%) were captured in the intradomicile and $272(38.5 \%)$ in the peridomicile $(\mathrm{p}<0.0001)$, $79.92 \%$ males and $20.08 \%$ females, belonging to three subtribes, five genera and five species: Lutzomyiina - Lutzomyia longipalpis (Lutz \& Neiva, 1912) and Evandromyia cortelezzii (Brethes, 1923); Bumptomyiina - Brumptomyia brumpti (Larousse, 1920); Psychodopygina - Nyssomyia whitmani (Antunes \& Coutinho, 1939) and Psathyromyia shannoni (Dyar, 1929) (Table 1).

Lu. longipalpis was the most frequent species, representing $686(97,03 \%)$ of specimens collected. It was also the only one found in all capture sites, occurring in only eight of 14 ecotopes of Ponta Porã.

Between April 2009 and March 2010, six cases of AVL and 50 cases of canine visceral leishmaniasis (CVL) were reported in Ponta Porã. The secondary data on the occurrence of human and canine cases and canines in the study areas, were obtained through the Department of State Health Mato Grosso do Sul and the Center for Zoonosis Control Ponta Porã (Table 2). These cases occurred in only three of the seven studied areas. No correlation was observed between the number of specimens caught and the number of canine cases $(\mathrm{r}=0.6841, \mathrm{p}=$ 0.0901), nor between the number of Lu. longipalpis and the number of human cases in the capture sites $(\mathrm{r}=$ 0.6761, $\mathrm{p}=0.0954$ ).

It can be observed that there is no correlation between NDWI and the number of sandflies captured in the urban area. Regarding NDVI and number of sandflies we note the absence of correlation between the variables, i.e., the value of NDVI (with high or low) did not affect the number of vectors captured.

On the other hand, there was a negative correlation between NDVI and the number of canine cases, i.e., the lower the value of NDVI (vegetation or phytomass) the larger the number of canine cases existing in Ponta Porã. No correlation was seen between NDVI and the number of sandflies captured in the urban area, i.e. the value of NDVI (either high or low) did not affect the number of sandflies captured.

The values for NDVI of the 7 capture sites can be observed in Figure 1.

The correction of these values in different capture sites was performed using the vegetation index adjusted to soil background (SAVI), as can be seen in Figure 2 .

The values for NDWI of the 7 capture sites were showed in Figure 3.

In Figure 1 it can be seen that, by the NDVI analysis, sites 2 and 6 presented median vegetation indexes (0.34 and 0.40). In Figure 2, after using SAVI, they came to present higher values. Site 3 was the one that showed the highest value of NDWI (the largest quantity of water).

Median values of water were obtained in sites 2, 5 and 6 , corresponding to moderate moisture content. In site 4 minimum values of vegetation and moisture were found by the three indices (NDVI, NDWI and SAVI). In this site there was a concentration of cases of human and canine VL, besides the capture of Lutzomyia longipalpis.

Table 1 Phlebotomines captured fortnightly with CDC automatic light traps, by species, sex and site of capture

\begin{tabular}{|c|c|c|c|c|c|c|c|c|c|c|c|c|c|c|c|c|c|c|}
\hline \multirow[t]{2}{*}{ Phlebotomines } & \multicolumn{2}{|c|}{ Site 01} & \multicolumn{2}{|c|}{ Site 02} & \multicolumn{2}{|c|}{ Site 03} & \multicolumn{2}{|c|}{ Site 04} & \multicolumn{2}{|c|}{ Site 05} & \multicolumn{2}{|c|}{ Site 06} & \multicolumn{2}{|c|}{ Site 07} & \multicolumn{3}{|c|}{ Total } & \multirow[b]{2}{*}{$\%$} \\
\hline & $M$ & $\mathbf{F}$ & $M$ & $F$ & $M$ & $F$ & $M$ & $F$ & $M$ & $F$ & $M$ & $F$ & $M$ & $F$ & $M$ & $F$ & MF & \\
\hline Br. brumpti & - & - & - & - & - & 01 & - & - & - & - & - & - & - & - & - & 01 & 01 & 0.14 \\
\hline Ev. cortelezzii & - & - & - & 02 & - & 03 & - & - & - & - & - & - & - & - & - & 05 & 05 & 0.71 \\
\hline Lu. longipalpis & 03 & - & 141 & 24 & 195 & 46 & 216 & 56 & - & 03 & 02 & - & - & - & 557 & 129 & 686 & 97.03 \\
\hline Ny. whitmani & - & - & 03 & 03 & 01 & 01 & - & - & - & - & - & - & - & - & 04 & 04 & 08 & 1.13 \\
\hline Ps. shannoni & - & - & - & - & 04 & 03 & - & - & - & - & - & - & - & - & 04 & 03 & 07 & 0.99 \\
\hline TOTAL & 03 & - & 144 & 29 & 200 & 54 & 216 & 56 & - & 03 & 02 & - & - & - & 565 & 142 & 707 & 100 \\
\hline
\end{tabular}


Table 2 NDVI, NDWI, SAVI, AVL cases and CVL cases in all sites of capture

\begin{tabular}{lccccc}
\hline & NDVI & NDWI & SAVI & AVL cases & CVL cases \\
\hline Site 01 & 0.406861 & -0.105564 & 0.608469 & - & 03 \\
Site 02 & 0.375183 & -0.047968 & 0.560971 & 01 & 19 \\
Site 03 & 0.269149 & -0.122483 & 0.402167 & - & - \\
Site 04 & 0.585989 & 0.100511 & 0.875453 & 05 & 28 \\
Site 05 & 0.458281 & -0.017563 & 0.684865 & - & - \\
Site 06 & 0.373158 & -0.047579 & 0.557827 & - & - \\
Site 07 & 0.332340 & -0.075027 & 0.496707 & - & - \\
\hline
\end{tabular}

\section{Discussion}

The survey conducted in Ponta Porã suggests that the dynamics of the species population studied is similar to that reported by Barretto [20] and Aguiar et al. [21] in studies in which captures with light traps were found to have the advantage of offering a greater number of males. As possible hypotheses, there is also the fact that male hatching occurs before the females or the fact that the traps are installed next to the breeding sites. The fact that there are pets in the peridomicile also raises the possibility that males are being attracted to kairomones released by vertebrate hosts existing in ecotopes (dogs, chickens, human beings). There may have been attraction to traps when monitoring females for mating, since male sandflies are known to form "lekking" aggregates for the purpose of mating [22,23].

The occurrence and predominance of Lu. longipalpis in the intradomicile suggests its adaptation to artificial environments created by man, that serve as shelter for adult forms [24]. The presence of dogs in intradomicile and not in peridomicile was observed during the period of capture. The presence of dogs inside the houses is also considered an important factor, as they can act as a food source for females, serving as potential reservoirs of the disease, according to studies of Bigeli; Oliveira-Júnior; Teles [25].

In this study a negative correlation between NDVI and reported canine cases was observed. The concentration occurred in the same area where low vegetation index, which features a modified environment, was found. This finding is important from an epidemiological point of view, because the dogs act as the main domestic reservoirs of Leishmania in urban areas [26].

Margonari et al. [27] observed the occurrence of human and canine leishmaniasis in areas with presence of vegetation, which differs from that found in Ponta Porã.

Even though there is no correlation between the cases of human AVL, reports of $L V C$ and the number of $L u$.

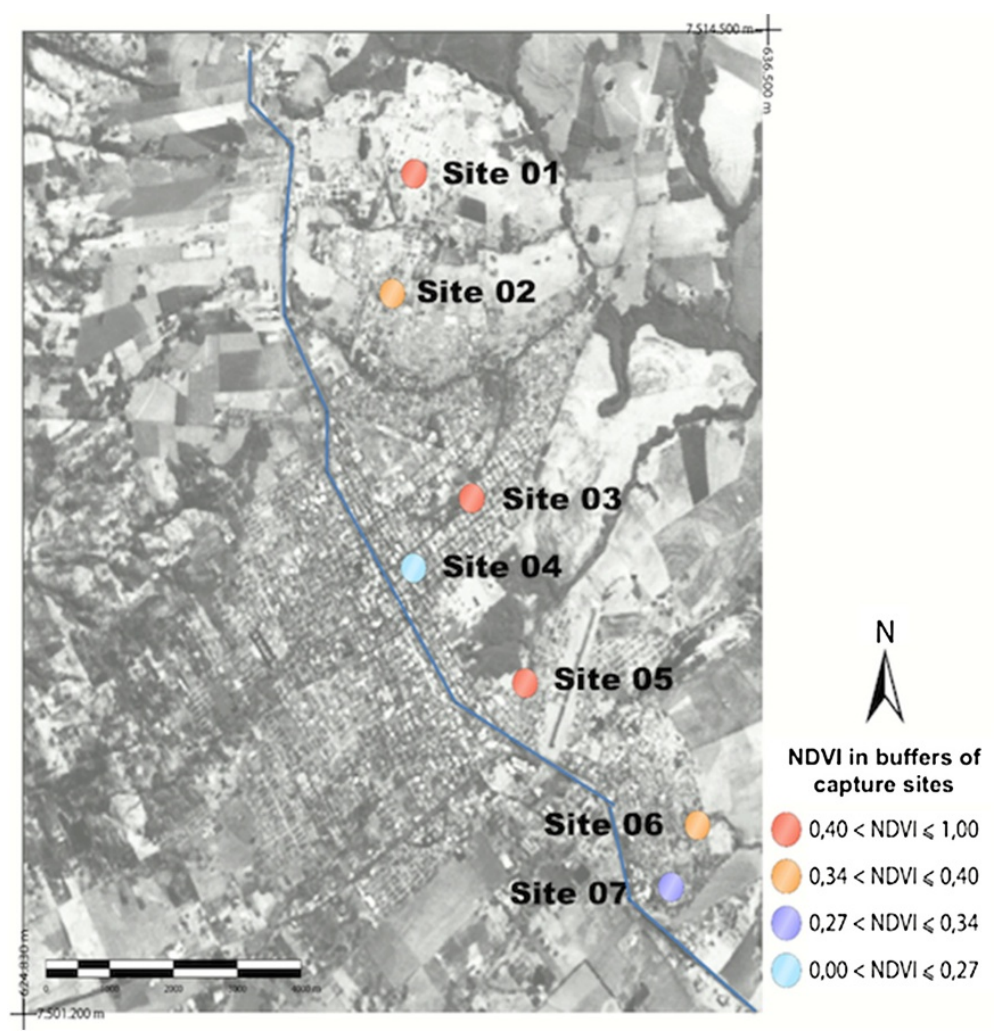

Figure 1 Landsat image with values of NDVI observed in the capture sites of the urban area of Ponta Porã, located on the right side of the map. 


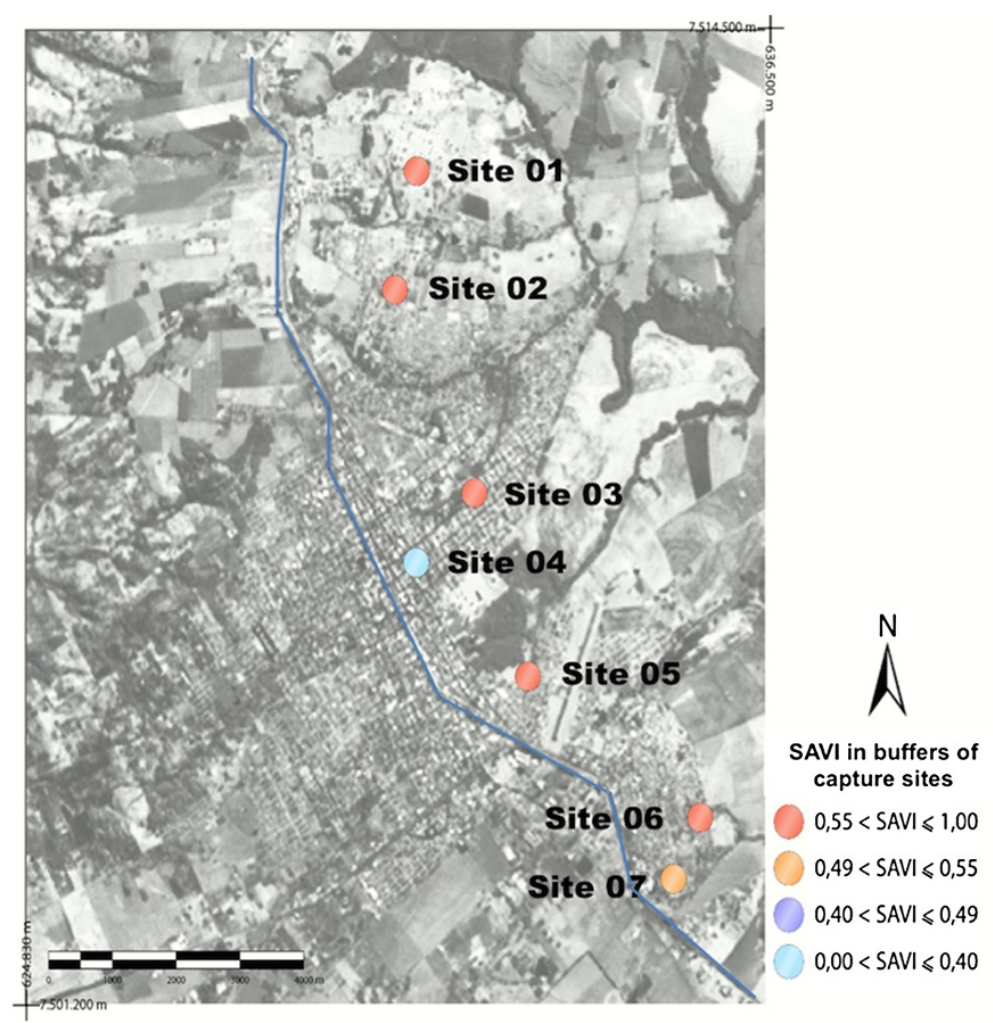

Figure 2 Landsat image with the values of SAVI. The figure shows, after correction, high values of vegetation in five of all seven sites studied.

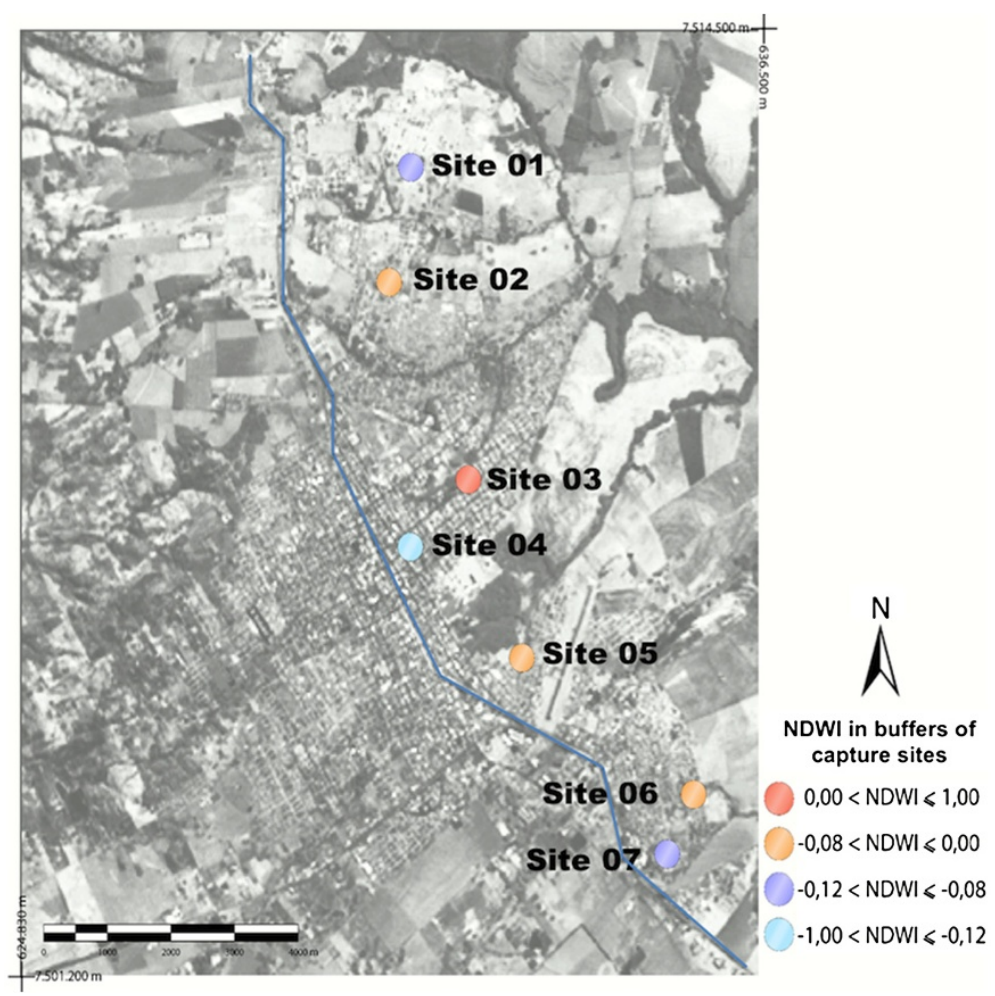

Figure 3 Landsat image with the values for the index of normalized difference by water (NDWI). 
longipalpis collected, the presence of potential reservoirs and vectors specific for the agent in the urban area is important from the perspective of epidemiological surveillance. Considering that dogs are the main links in the epidemiological chain of disease in urban areas, and that many sandflies were collected in areas where the cases occurred, actions to control the disease must have priority [25,28-30].

There are no records of studies aiming to assess vegetation and its relation to the spatial distribution of vectors in areas of bordering countries. In Ponta Porã the analysis of vegetation cover by NDVI showed the presence of vegetation at high levels in three of the seven sites chosen. After using SAVI, five of the seven capture sites showed high levels of phytomass.

The central area of the city presents high values of NDVI, NDWI and SAVI, and also a wider diversity of phlebotomine species, which can be explained by the fact that Ponta Porã is surrounded by land with remnants of native forest, suggesting a higher degree of moisture in the environment, thus maintaining favorable conditions for vector development [9]. This result corroborates the findings of Fernandez et al. [31] that associated species to the presence of trees and bushes near capture sites in the urban area, which was also described by Cutolo, Camargo and Zuben [32] in studies developed in the southeastern region of Brazil.

In the State of Mato Grosso do Sul, Oliveira et al. [33] observed a wider diversity of species in forested areas in a study carried out in Campo Grande. Nunes et al. [34] also made this association in a survey conducted in Bonito. The association of vectors and areas with high vegetation index was also observed in a study performed in Campo Grande (MS) by Oliveira et al. [5]. Among the possible shelters for the sandflies described by Forattini [9], vegetation is suitable for maintaining breeding sites of winged and larval forms, presenting a wider diversity not only of plants that serve as a food source for males, but also vertebrate hosts acting as a food source for females.

NDWI is directly related to the water content in vegetation and soil moisture. It is an important fact since larval stages of sandflies require a humid environment, as noted by Amaral et al. [35]. There is no report in the literature as to an association of this index with the issue of leishmaniases.

The concentration of human and canine cases in a place where there was a greater capture of vectors was also observed by Prado et al. [29] in Montes Claros (MG); and Bigeli, Oliveira-Junior and Teles [25] in Palmas (TO). In Bahia, Carneiro et al. [28] observed low values of NDVI in sites where the numbers of human cases and the records of Lu. longipalpis were both high, which may suggest human activities on vegetation, corroborating what was observed in Ponta Porã.
The evaluation of moisture in the vegetation studied by NDWI is extremely important because it is directly linked to the development conditions of the insect's immature form. The collection of Lu. longipalpis in all months of the year, associated with the presence of the sandfly in sites of low humidity, indicates that there is not a sole characteristic environment with specific conditions for the development and survival of these vectors.

\section{Conclusions}

The finding of $\mathrm{Lu}$. longipalpis in regions with little vegetation and humidity suggests that the species are adapted to different sorts of environmental conditions, demonstrating its close association with man and the environment he inhabits. The tourist feature of Ponta Porã reinforces its epidemiological importance as a vulnerable city. The geographical location, bordering Paraguay through dry borders, makes possible the existence of a corridor of vectors and infected dogs between the two countries.

\section{Competing interests}

The authors declare that they have no competing interests.

\section{Authors' contributions}

AROA, RA conceived and designed the study; AROA, GC, APF, AR collected the data; AROA, BAKS analyzed data; AROA, BAKS, SMOA, MFCS wrote the manuscript. All authors read and approved the final version of the manuscript.

\section{Acknowledgments}

The research was supported by Coordenação de Aperfeiçoamento de Pessoal de Nível Superior - CAPES (Coordination for the Improvement of Higher Level Personnel) (Grant No. 2009/0369).

\section{Author details}

${ }^{1}$ Post Graduate Program in Infectious and Parasitary Diseases, Federal University of Mato Grosso do Sul, Campus Universitário, s/n, Caixa Postal 549, CEP 79070-900 Campo Grande, Mato Grosso do Sul, Brasil. ${ }^{2}$ Center of Health Sciences, Federal University of Piauí, Campus Universitário Ministro Reis Velloso, Av. São Sebastião 2819, Bairro São Benedito, CEP 64202-020 Parnaíba, Piauí, Brasil. ${ }^{3}$ Human Parasitology Laboratory, Federal University of Mato Grosso do Sul, Campus Universitário, s/n, Caixa Postal 549, CEP 79070-900 Campo Grande, Mato Grosso do Sul, Brasil. ${ }^{4}$ Post Graduate Program in Health and Development of the Central West Region, Federal University of Mato Grosso do Sul, Campus Universitário, s/n, Caixa Postal 549, CEP 79070-900 Campo Grande, Mato Grosso do Sul, Brasil. ${ }^{5}$ Geotechnology Laboratory, Federal University of Mato Grosso do Sul, Campus Universitário, s/n, Caixa Postal 549, CEP 79070-900 Campo Grande, Mato Grosso do Sul, Brasil. ${ }^{6}$ Embrapa Beef Cattle, Campo Grande, BR 262 km 4 - Caixa Postal 154, CEP 79002-970 Campo Grande, Mato Grosso do Sul, Brasil.

Received: 22 January 2014 Accepted: 15 May 2014 Published: 4 June 2014

\section{References}

1. Brazil RP, Caballero N, Hamilton JGC: Identification of the sex pheromone of Lutzomyia longipalpis (Lutz \& Neiva, 1912) (Diptera: Psychodidae) from Asunción, Paraguay. Parasit Vectors 2009, 51:1-3.

2. Dorval MEC, Alves TP, Cristaldo G, Rocha HC, Alves MA, Oshiro ET, Oliveira AG, Brazil RP, Galati EAB, Cunha RV: Sand fly captures with Disney traps in area of occurrence of Leishmania (Leishmania) amazonensis in the State of Mato Grosso do Sul, mid-western Brazil. Rev Soc Bras Med Trop 2010, 43:491-495

3. Almeida OS, Nascimento JC, Ferreira AD, Minzão LD, Portes F, Miranda FAM, Faccenda O, Andrade-Filho JD: Espécies de flebotomíneos (Diptera, 
Psichodidade) coletadas em ambiente urbano em municípios com transmissão de Leishmaniose Visceral do Estado de Mato Grosso do Sul, Brasil. Rev Bras Entomol 2010, 54:304-310.

4. Oliveira JM, Fernandes AC, Dorval MEC, Alves TP, Fernandes TD, Oshiro ET, Oliveira AL: Mortalidade por leishmaniose visceral: aspectos clínicos e laboratoriais. Rev Soc Bras Med Trop 2010, 43:188-193.

5. Oliveira EF, Silva EA, Fernandes CES, Paranhos-Filho AC, Gamarra RM, Ribeiro AA, Brazil RP, Oliveira AG: Biotoc factors and occurrence of Lutzomyia longipalpis in endemic area of visceral leishmaniasis, Mato Grosso do Sul, Brazil. Mem Inst Oswaldo Cruz 2012, 107:396-401.

6. Lainson R, Rangel EF: Lutzomyia longipalpis and the eco-epidemiology of American visceral leishmaniasis, with particular reference to Brazil: a review. Mem Inst Oswaldo Cruz 2005, 100:811-827.

7. Antonialli SAC, Torres TG, Paranhos-Filho AC, Tolezano JE: Spatial analyses of American Visceral Leishmaniasis, in Mato Grosso do Sul, State, Central-Brazil. J Infect 2007, 54:509-514.

8. IBGE (Brazilian Institute of Geography and Statistics): IBGE cidades: Ponta Porã. [http://www.ibge.gov.br/estadosat/perfil.php?sigla=ms\#].

9. Forattini OP: Entomologia médica. Psychodidae, phlebotominae, leishmanioses, bartonelose. São Paulo: Edgard Blucher/USP; 1973.

10. Galati EAB: Morfologia e taxonomia: classificação de Phlebotominae. In Flebotomíneos do Brasil. Edited by Ragel E, Lainson R. Rio de Janeiro: Fiocruz; 2003.

11. Galati EAB: Phlebotominae (Diptera, Psychodidae): morfologia e terminologia de adultos. São Paulo: Departamento de Epidemiologia/Faculdade de Saúde Pública/Universidade de São Paulo; 2004.

12. Marcondes CB: A proposal of generic and subgeneric abbreviations for phlebotomine sandflies (DIPTERA: PSYCHODIDAE: PHLEBOTOMINAE) of the world. Entomol News 2007, 118:351-356.

13. INPE (National Institute for Space Research): LANDSAT TM. 2010. Imagem de satélite. Canais 1,2,3,4,5 e 7. Órbita/Ponto: 225/075. [http://www.inpe.br].

14. GLCF Global Land Cover Facility/ U.S. Geological LANDSAT TM: Imagem de satélite. Canais 1,2,3,4,5 e 7. Órbita/Ponto:225/073. [http://glcf.umd.edu/ index.shtml].

15. PCI GEOMATICS: PCI Geomática, V. 10.2.1 for Windows. Ontário, Canadá: 1 CD-ROOM; 2009

16. de Rousse JW, Haas RH, Schell JA, Deering DW: Monitoring vegetation systems in the Great Plains with ERTS. Nasa 1974, 1:309-317.

17. Ponzoni FJ, Shimabukuro YE: Sensoriamento remoto no estudo da vegetação. São José dos Campos: Parêntese; 2007.

18. Huete AR: A soil-adjusted vegetation index (SAVI). Remote Sens Environ 1988, 25:295-309.

19. Gao BC: NDWI: a normalized difference water index for remote sensing of vegetation liquid water from space. Remote Sensing Environ 1996, 58:257-266

20. Barreto MP: Observações sobre a Biologia, em Condições Naturais, dos Flebótomos do Estado de São Paulo (Diptera, Psychodidae), PhD Thesis. São Paulo, Brazil: Faculdade de Medicina-University of São Paulo - USP; 1943.

21. Aguiar GM, Vilela ML, Schuback PA, Soucasaux T, Azevedo ACR: Aspectos da ecologia dos flebótomos do Parque Nacional da Serra dos Órgãos, Rio de Janeiro: IV. Frequência mensal em armadilhas luminosas (Diptera, Psychodidae, Phlebotominae). Mem Inst Oswaldo Cruz 1985, 80:465-482.

22. Kelly DW, Dye C: Pheromones, kairomones and the aggregation dynamics of the sandfly Lutzomyia longipalpis. Anim Behav 1997, 53:721-731.

23. Feliciangeli MD: Ecology of sandflies (Diptera: Psychodidae) in a restricted focus of cutaneous leishmaniasis in northern Venezuela. I. Description of the study area, catching methods and species composition. Mem Inst Oswaldo Cruz 1987, 82:119-124.

24. Rangel EF, Vilela ML: Lutzomyia longipalpis (Diptera, Psychodidae, Phlebotominae) e urbanização da leishmaniose visceral no Brasil. Cad Saude Publica 2008, 24:2948-2952.

25. Bigeli JG, Oliveira-Júnior WP, Teles NMM: Identificação de cães infectados por Leishmania (Leishmania) chagasi e sua relação com aspectos ambientais e sanitários no município de Palmas, Estado do Tocantins, Brasil. Rev Soc Bras Med Trop 2012, 42:18-23.

26. Dantas-Torres F: Canine leishmaniasis in South America. Parasit Vectors 2009, 2:1-8.

27. Margonari C, Freitas CR, Ribeiro RC, Moura ACM, Timbó M, Gripp AC, Pessanha JE, Dias ES: Epidemiology of visceral leishmaniasis through spatial analysis, in Belo Horizonte municipality, state of Minas Gerais, Brazil. Mem Inst Oswaldo Cruz 2006, 101:31-38.

28. Carneiro D, Bavia ME, Rocha W, Lobão J, Madureira-Filho C, Oliveira JB, Silva CE, Barbosa MG, Rios R: Identificação de áreas de risco para leishmaniose visceral americana, através de estudos epidemiológicos e sensoriamento remoto orbital, em Feira de Santana, Bahia, Brasil (2000-2002). Rev Baiana Saude Pub 2004, 28:19-32.

29. Prado PF, Rocha MF, Sousa JF, Caldeira DI, Paz GF, Dias ES: Epidemiological aspects of human and canine visceral leishmaniasis in Montes Claros, state of Minas Gerais, Brazil, between 2007 and 2009. Rev Soc Bras Med Trop 2011, 44:561-566.

30. Vieira LRL, Carneiro LA, Campos MB, Chagas EJ, Laurenti MD, Corbett CEP, Lainson R, Silveira FT: Canine Visceral leishmaniasis due to Leishmania (L.) infantum chagasi in Amazonian Brazil: Comparison of the parasite density from the skin, lymphnode and visceral tissues between symptomatic and asymptomatic, seropositive dogs. Rev Inst Med Trop de São Paulo 2010, 52:259-265.

31. Férnandez MS, Salómon OD, Cavia R, Perez AA, Acardi SA, Guccione JD: Lutzomyia longipalpis spatial distribution and association with environmental variables in an urban focus of visceral leishmaniasis, Misiones, Argentina. Acta Trop 2010, 114:81-87.

32. Cutolo AA, Camargo DA, Zuben CJV: Novos registros de Lutzomyia longipalpis (Lutz \& Neiva, 1912) (Diptera: Psychodidae) na região centro-leste do Estado de São Paulo, Brasil. Rev Bras Parasitol Vet 2009, 18:62-65.

33. Oliveira AG, Andrade-Filho JD, Falcão AL, Brazil RP: Estudo da fauna flebotomínea (Diptera: Psychodidae, Phlebotominae) na zona urbana da Cidade de Campo Grande, Mato Grosso do Sul, Brasil, 1999-2000. Cad Saude Publica 2003, 19:933-944.

34. Nunes VLB, Galati EAB, Cardozo C, Rocca MEG, Andrade ARO, Santos MFC, Aquino RB, Rosa D: Estudo de flebotomíneos (Diptera, Psychodidae) em área urbana de município de Bonito, Mato Grosso do Sul, Brasil. Rev Bras Entomol 2008, 52:446-451.

35. Amaral AFS, Varjão JR, Silva GB, Arrais-Silva WW: Fauna flebotomínica (Diptera: Psychodidae: Phlebotominae) em área residencial e em fragmento de cerrado no município de Pontal do Araguaia, Mato Grosso, Brasil. Rev Bras Parasitol Vet 2011, 20:165-167.

doi:10.1186/1756-3305-7-260

Cite this article as: de Andrade et al: Spatial distribution and environmental factors associated to phlebotomine fauna in a border area of transmission of visceral leishmaniasis in Mato Grosso do Sul, Brazil. Parasites \& Vectors 2014 7:260.

\section{Submit your next manuscript to BioMed Central and take full advantage of:}

- Convenient online submission

- Thorough peer review

- No space constraints or color figure charges

- Immediate publication on acceptance

- Inclusion in PubMed, CAS, Scopus and Google Scholar

- Research which is freely available for redistribution 